\title{
Spanish Goat Diets on Mixed-brush Range- land in the South Texas Plains
}

\author{
L.E. WARREN, D.N. UECKERT, M. SHELTON, AND A.D. CHAMRAD
}

\begin{abstract}
Microhistological analysis of feces from Spanish goats (Capra hircus) graxing in a mixed-brush complex in the South Texas Plains indicated that shrubs were their major foods during autumn, winter, and summer. Grasses were the major diet item during spring. Forbs, which were relatively scarce due to poor growing conditions during the 13-month study, were of minor importance in goat diets. The importance in Spanish goat diets of several problem brush species, including blackbrush acacia (A cacia rigidula), condalias (Condalia spp.), guajillo (A cacia berlandieri), guayacan (Porliera angustifolia), and wolfberry (Lycium berlandieri), suggests a potential for utilizing these animals in conjunction with other brush management practices for more effective shrub control and for increasing efficiency of forage utilization on mixed-brush rangeland.

The South Texas Plains are approximately 8 million ha which historically supported grassland or savannah type vegetation (Thomas 1975). Long-term continuous grazing, periodic droughts, and the reduced frequency and intensity of fires have resulted in a

\footnotetext{
Authors are research associate, professors, repectively with Texas Agricultural Experiment Station San Angelo 76901; and associate professor, Texas Agricultural Experiment Station, Uvalde 78801

This article is approved by the Director, Texas Agricultural Experiment Station as TA-18166.

The authors express appreciation to Steve, Tom, and Mike Walker for providing land for this study, to P.H. Coates 111 for providing the goats, and to R.L. Potter for assistance with data analyses. This research was funded by the United States Agency for International Development Title XII Small Ruminants Collaborative Research Support Program under Grant No. AID/DSAN/XII-G-0049, in collabroation with Empresa Braisileira de Pesquisa Agro-pecuaria; Brazil.

Manuscript received November 18, 1982.
}

dense mixed-brush vegetation type in the central and western South Texas Plains, which is one of the most difficult-to-manage brush problems in the state. A variety of low-growing, xerophytic shrubs, including honey mesquite (Prosopis glandulosa Torr. var. glandulosa), acacias (Acacia spp.), condalias (Condalia spp.), spiny hackberry (Celtis pallida), cenizo (Leucophyllum frutescens), agarito (Berberis trifoliolata), and cacti (Opuntia spp.) dominate typical South Texas mixed-brush communities (Scifres 1980). The increasing costs of herbicidal and mechanical brush control practices are forcing ranchers in the South Texas Plains to seek less expensive practices for management of mixed-brush rangeland.

Goating has been used for many years in certain areas of Texas and the Southwest for control or suppression of undesirable brush (Vallentine 1971, Merrill and Taylor 1976, Scifres 1980). The effectiveness of goating as a biological brush management practice depends on the size and species composition of the brush population, as well as on proper adjustment of stocking rate, duration, and frequency of grazing periods to intensity of the brush problem. Management of predators is usually necessary in areas where goats are grazed.

Oates (1956) demonstrated that goats can kill certain brush species, such as Acacia spp., without harming desirable forage plants. Goats can also effectively control or suppress oaks ( $Q$ uercus spp.) and juniper (Juniperus spp.) (Magee 1957, Norris 1968). Merrill and Taylor (1976) reported that Spanish goats completely consumed new growth of shin oak ( $Q$. mohriana), hackberry (Celtis reticulata), and pricklyash (Zanthoxylum sp.), while Angora 
goats (Capra hircus) utilized only about $30 \%$ of the shin oak and $80 \%$ of the hackberry and pricklyash. Warren et al. (1984) also found that Spanish goats consumed more browse than did Angora goats. However, they reported that neither Spanish goats, Angora goats, nor Rambouillet, Karakul, or Barbado sheep (Ovis aries) consumed appreciable quantities of the major undesirable brush species, including honey mesquite, creosotebush (Larrea tridentata), tarbush (Flourensia ceruna), juniper, lotebush (Condalia obtusifolia), catclaw acacia (Acacia greggii), and agarita, on 3 study sites in western Texas. Goats feed over rugged terrain, and can be combined with other livestock to optimize utilization of vegetation (Campbell et al. 1962). Fraps and Cory (1940) concluded that goats, as compared to cattle or sheep, had a greater tendency to alter their diet with changing seasons and forage conditions.

Addition of goats to grazing management systems in the South Texas Plains could substantially improve total forage utilization and diversify income sources for ranchers. Ideally, goats would suppress, as well as provide a means of marketing brush, and the improvement in range condition and sale of goat products would pay for predator control practices required for maintenance of the goat herd. We conducted a study during 1979-1980 to determine the extent to which Spanish goats graze the native shrubs on mixed-brush rangeland on the South Texas Plains.

\section{Methods}

The 81-ha experimental pasture, located on the Walker Ranch in southern McMullen County, was predominately a Shallow Sandy Loam range site typified by Randado and Hildalgo sandy clay loams. Average annual precipitation is about $50 \mathrm{~cm}$ but only $25 \mathrm{~cm}$ fell during the study period. The vegetation was a mixed-brush complex consisting primarily of guajillo (Acacia berlandieri), blackbrush acacia (Acacia rigidula), kidneywood (Eysenhardtia texana), and cenizo. Major grasses included threeawns (Aristida spp.), pink pappusgrass (Pappophorum bicolor), red grama (Bouteloua trifida), and curlymesquite (Hilaria belangeri). Associated forbs were Indianmallow (Abutilon incanum), verbena (Verbena sp.), ragweed (Ambrosia sp.), and pepperweed (Lepidium sp.).

The pasture, which was grazed by cattle prior to this study, was fenced with electrically charged smooth wires arranged to exclude coyotes (Canis latrans), then stocked with 50 Spanish goats in September 1979. A composite fecal sample comprised of 10 fresh, single defecations was collected each month from October 1979 through October 1980. Five microscope slides were prepared from each fecal sample. Approximate dry weight composition of Spanish goat diets was determined by examination of plant epidermal tissues at $100 \mathrm{X}$ magnification in 20 fields on each slide (Sparks and Malechek 1968). Plant tissues were identified by epidermal cellular characteristics from reference tissue of identified plants collected from the study area.

Fecal analysis generally results in higher estimates of grasses, trees, and shrubs, and lower estimates of forbs in herbivore diets as compared to estimated values obtained by other techniques due to differential digestibility of these foods (Anthony and Smith 1974, Vavra et al. 1978, Holechek et al. 1982, McInnis et al. 1983). However, dietary trends and relative importance value rankings of individual plant species in diets as determined by fecal analysis are accurate (Vavra et al. 1978). In the authors' opinion, the microscopic examination of fecal material was adequate for accomplishing the objective of this study.

Monthly diet data were grouped by seasons and subjected to multivariate analysis of variance to determine seasonal effects. Seasonal effects were masked by variation within seasons, consequently diet data for individual food items were subjected to oneway analysis of variance to determine seasonal differences.

\section{Results and Discussion}

Twenty-nine plant species were identified in Spanish goat diets
(Table 1). Grasses contributed over half of the goat diets during spring, but less than $20 \%$ in autumn. Grama grasses, primarily red grama, were the major grass food of Spanish goats. Curlymesquite and threeawns contributed $10 \%$ or more to goat diets in summer and spring. Panicums (Panicum spp.), a minor diet component, were more important in goat diets in spring, compared to autumn and summer $(P \leq 0.05)$. Differences among seasonal means for other grass foods were not significant at $P \leq 0.05$, although seasonal differences were detected for grama grasses and curlymesquite at $P \leq 0.10$. McInnis et al. (1983) reported that fecal analysis overestimated the grass in sheep diets by $15 \%(65 \%$ grass in known diet mixture vs. $80 \%$ grass in feces). Thus our data may slightly overestimate the importance of grasses in Spanish goat diets.

Table 1. Mean seasonal diets (\%) of Spanish goats grazing in southern McMullen County of the South Texas Plains.'

\begin{tabular}{|c|c|c|c|c|}
\hline \multirow[b]{2}{*}{ Foods } & \multicolumn{4}{|c|}{ Season } \\
\hline & Autumn & Winter & Spring & Summer \\
\hline \multicolumn{5}{|l|}{ Grasses } \\
\hline Bouteloua spp. & 10 & 20 & 29 & 17 \\
\hline Hilaria belangeri & 3 & 7 & 7 & 10 \\
\hline $\begin{array}{l}\text { Panicum spp. } \\
\text { Aristida spp. }\end{array}$ & $<1 b$ & $\begin{array}{l}2 a b \\
8\end{array}$ & $12 \mathrm{a}$ & $\begin{array}{l}0 \mathrm{~b} \\
4\end{array}$ \\
\hline Other grasses ${ }^{2}$ & 3 & 3 & 3 & 4 \\
\hline Total grasses & 17 & 40 & 54 & 35 \\
\hline \multicolumn{5}{|l|}{ Forbs } \\
\hline Abutilon incanum & 2 & $<1$ & 2 & 2 \\
\hline Other forbs ${ }^{3}$ & 5 & $<1$ & 1 & 6 \\
\hline Total forbs & 7 & 1 & 3 & 8 \\
\hline \multicolumn{5}{|l|}{ Shrubs } \\
\hline Acacia spp. & 24 & 11 & 0 & 10 \\
\hline Porliera angustifolia & 10 & 7 & 4 & 6 \\
\hline Leucophyllum frutescens & $10 \mathrm{ab}$ & $15 \mathrm{a}$ & ic & $4 \mathrm{bc}$ \\
\hline Condalia spp. & 15 & 12 & 13 & 21 \\
\hline Acacia berlandieri & 5 & 4 & 7 & 3 \\
\hline Eysenhardtia texana & $<1$ & 1 & 2 & 1 \\
\hline Aloysia lyciodes & 3 & 0 & 0 & 1 \\
\hline Lycium berlandieri & 0 & 0 & 9 & 6 \\
\hline Other shrubs 4 & $<1$ & 2 & 4 & $\leq 1$ \\
\hline Total shrubs & 68 & 52 & 40 & 52 \\
\hline
\end{tabular}

Succulents

Opuntia spp.

5

7

5

4

IMeans within a row followed by similar lower case letters are not significantly different at $P \leq 0.05$.

${ }^{2}$ Grasses that contributed less than $1 \%$ of Spanish goat diets included Sporobolus sp., Pappophorum bicolor, Bothriochloa sp., Stipa leucotricha, and unidentifiable grasses.

${ }^{3}$ Forbs that contributed less than $1 \%$ of Spanish goat diets included Verbena sp., Lepidium sp., Croton sp., Lesquerella sp., and unidentifiable forbs.

4Shrubs that contributed less than $1 \%$ of Spanish goat diets included Bumelia celastrina. Forestiera angustifolia, Schaefferia cuneifolia, Diospyros texana, Rhus microphylla, Koeberlinia spinosa, and Yucca sp.

Forbs, which were relatively scarce during the study due to poor growing conditions, were a minor component in the seasonal diets of Spanish goats (Table 1). Indianmallow was the most important forb in goat diets. Forbs contributed 13\% of the diet in June 1980 and $18 \%$ during October 1980 , but $5 \%$ or less during other autumn months and in winter and spring. McInnis et al. (1983) found that fecal analysis underestimated total forbs in sheep diets by $15 \%$ (35\% forbs in known diet mixture vs. $20 \%$ forbs in feces). Our data may underestimate the actual amount of forbs in Spanish goat diets, but we believe they were accurately ranked in terms of relative importance.

Shrubs were the most important foods of Spanish goats, contributing over half the diet in summer, autumn, and winter (Table 1). Major shrubs in goat diets were blackbrush acacia, guajillo, other species of Acacia, condalias, guayacan (Porliera angustifolia), and cenizo. Browse made up half to three-fourths of the diets of Spanish 
goats in all months except during February through May. Green foliage is usually present on most shrub species in the mixed-brush complex yearlong, due to mild winter temperatures. Two evergreen shrubs, guayacan and cenizo, were major foods of Spanish goats during the winter. Cenizo was significantly more important in goat diets in autumn and winter than in spring, and was more important in winter than in summer $(P \leq 0.05)$. A seasonal effect was significant at $P \leq 0.10$ for the $A$ cacia spp. group (A. rigidula and $A$. tortuosa), but no seasonal effects were detected for other shrubs. Blackbrush acacia retains some green foliage during most winters. Wolfberry (Lycium berlandieri), a drought-deciduous shrub, was a major food of Spanish goats during May (26\%), June (8\%), and July (10\%).

Browse was more important than grasses in Spanish goat diets in all months except February, March, and May. Our data probably slightly overestimate the amount of browse in Spanish goat diets. Smith and Shandruk (1979) reported that fecal analysis overestimated the amount of sagebrush (Artemisia tridentata) in tame mule deer (Odocoileus hemionus) diets by about $19 \%$ (9.5\% in known diet mixture vs. $28.8 \%$ in feces) and overestimated the a mount of juniper (Juniperus osteosperma) by about $2.7 \%(0.34 \%$ in known diet mixture vs. $3.1 \%$ in feces).

Pricklypear (Opuntia spp.) was eaten by Spanish goats in all months except May and June, and made up $10 \%$ or more of the diet during January, April, and September.

These data confirm that Spanish goats readily eat a number of native shrubs that are common on the South Texas Plains. The importance of browse in Spanish goat diets during autumn, early winter, and late summer suggests that goats might compete with white-tailed deer (Odocoileus virginianus) during these periods. White-tailed deer also appear to prefer forbs when they are available (Chamrad et al. 1979). The importance of grasses in Spanish goat diets during February, March, and May suggests possible competition with cattle during these periods. However, since shrubs that are rapidly eaten by Spanish goats are so abundant, there appears to be a high potential for grazing goats, along with cattle and deer, to more efficiently harvest the available forage resource. Further research appears warranted to determine whether Spanish goats can be utilized for control or suppression of South Texas mixed-brush. It is the author's opinion that goating would be most effective when used to suppress brush resprouts following mechanical brush control practices, herbicide applications, or prescribed fire. The loss of $60 \%$ of the experimental goat herd to coyotes during this 13-month study emphasizes that effective pre- dator management will be essential before goating can be considered as a feasible brush management practice on the South Texas Plains.

\section{Literature Cited}

Anthony, R.G., and N.S. Smith. 1974. Comparison of rumen and fecal analysis to describe deer diets. J. Wildl. Manage. 38:535-540.

Campbell, Q.P., J.P. Ebershon, and H.H. von Broembsen. 1962. Browsing by goats and its effect on the vegetation. Herb. Abstr. 32:273-275.

Chamrad, A.D., B.E. Dahl, J.G. Kle. 1979. Deer food habits in South Texas-status, needs, and roles in resource management. p. 133-142. In: D.L. Drawe (ed.). Proc. First Welder Wildlife Foundation Symposium. Welder Wildlife Foundation, Sinton, Texas.

Fraps, G.S., and V.L. Cory. 1940. Composition and utilization of range vegetation of Sutton and Edwards counties. Tex. Agr. Exp. Sta. Bull. 586.

Holecheck, J.L., M. Vavra, and R.D. Pieper. 1982. Botanical composition determination of range herbivore diets: A review. J. Range Manage. 35:309-315.

Magee, A.C. 1957. Goats pay for clearing Grand Prairie rangelands. Tex. Agr. Exp. Sta. Misc. Pub. 206.

MeInnis, M.L., M. Vavra, and W.C. Krueger. 1983. A comparison of four methods used to determine the diets of large herbivores. J. Range Manage. 36:302-306.

Merrill, L.B. and C.A. Taylor. 1976. Take note of the versatile goat. Rangeman's J. 3:74-76.

Norris, J.B. 1968. Biological control of oak. Abst. 21st Ann. Meeting Amer. Soc. Range Manage.

Oates, A.V. 1956. Goats as a possible weapon in the control of thorn bush. Rhod. Agr. J. 53:68-85.

Seifres, C.J. 1980. Brush Management. Principles and Practices for Texas and the Southwest. Texas A\&M University Press. College Station.

Smith, A.D. and L.J. Shandruk. 1979. Comparison of fecal, rumen and utilization methods for ascertaining pronghorn diets. J. Range Manage. 32:275-279.

Sparks, D.R. and J.C. Malechek. 1968. Estimating percentage dry weight in diets using a microscopic technique. J. Range Manage. 21:264-265.

Thomas, G.W. 1975. Texas plants-an ecological summary. p. 7-14. In: F.W. Gould. Texas plants-a checklist and ecological summary. Tex. Agr. Exp. Sta. MP 585.

Vallentine, J.F. 1971. Range Development and Improvements. Brigham Young University Press. Provo, Utah.

Vavra, M., R.W. Rice, and R.M. Hansen. 1978. A comparison of esophageal fistula and fecal material to determine steer diets. J. Range Manage. 31:11-13.

Warren, L.E., D.N. Ueckert, and J.M. Shelton. 1984. Comparative diets of Rambouillet, Barbado, and Karakul sheep and Spanish and Angora goats. J. Range Manage. 37:172-180.

\title{
Announcing the 1985 Annual Meeting of the Society for Range Management:
}

\author{
Hotel Utah \\ Salt Lake City, Utah \\ February $11-14,1985$
}

You are invited to join the expected 1,500 range professionals who will gather in Salt Lake City, Utah, at the Hotel Utah for the 1985 Annual Meeting of the Society for Range Management. February 11 - 14, 1985. 